\title{
Juvenile gout: rare and aggressive
}

\author{
Celia Coelho Henriques, ${ }^{1}$ Agostinho Monteiro, ${ }^{1}$ Begoña Lopéz, ${ }^{1}$ Luís Sequeira, ${ }^{2}$ António Panarra, ${ }^{1}$ \\ Nuno Riso ${ }^{1}$
}

1Department of Internal Medicine 2, Curry Cabral Hospital, Lisbon, Portugal;

${ }^{2}$ Department of Physiatrics and Rehabilitation, Hospital Curry Cabral, Lisbon, Portugal

Correspondence to Dr Celia Coelho Henriques, celia.c.henriques@gmail.com

\section{DESCRIPTION}

A 32-year-old male patient presented with an acute polyarticular gout attack. Gout diagnosis was made 16 years before by isolation of monosodium urate crystals in synovial liquid. He had a frequency of four to five attacks of gout per year. Acute attacks were treated with non-steroidal anti-inflammatory drugs (ibuprofen) and colchicine. He was on no long-term medications. There was no family history of gout. On examination he was hypertensive (blood pressure of $162 / 91 \mathrm{~mm} \mathrm{Hg}$ ) and his body mass index was normal, of $19 \mathrm{~kg} / \mathrm{m}^{2}$. He had important articular deformity of both hands (figure 1A,B) with inflammatory signs in multiple joints (interphalangeal and metacarpophalangeal joints, wrists and knees) and numerous tophi in hands and ears. Blood tests performed showed an elevated serum uric acid level of $10.3 \mathrm{mg} / \mathrm{dl}$, elevated inflammatory markers (erythrocyte sedimentation rate $89 \mathrm{~mm} / \mathrm{h}$ and $\mathrm{C}$ reactive protein $5.6 \mathrm{mg} / \mathrm{dl}$ ), normocytic, normochromic anaemia (with haemoglobin of $10.1 \mathrm{~g} / \mathrm{dl}$ ) and a mild renal failure with creatinine of $1.6 \mathrm{mg} / \mathrm{dl}$, urea of $67 \mathrm{mg} / \mathrm{d}$ (estimated creatinine clearance of $56 \mathrm{ml} / \mathrm{min}$ ). Considering the association of gout with metabolic syndrome, a metabolic profile was performed: He had normal lipid levels, fasting blood glucose level of $92 \mathrm{mg} / \mathrm{dl}$ and $\mathrm{HbA}_{1 \mathrm{c}}$ of $5.4 \%$. Hands x-ray revealed exuberant joint destruction predominantly in carpal and distal interphalangeal joints (figure 2). Genetic investigations were not performed. The acute attack was treated with non-steroidal anti-inflammatory drugs and corticosteroids. Subsequently, he was treated with allopurinol and antihypertensive therapy and has remained asymptomatic for approximately 6 months. Gout is the most common form of inflammatory arthritis, characterised by elevation in serum uric acid levels and deposition of uric acid crystals in the joints. The findings of several studies suggest that the prevalence and incidence of gout has risen in recent decades. ${ }^{1}$ Juvenile chronic gout in its polyarticular destructive form has rarely been described in medical literature. ${ }^{2}$ Elevations in serum acid uric levels in young individuals are often associated with other underlying diseases (for example, some genetic disorders, myeloproliferative and lymphoproliferative diseases) or allied, reversible conditions that include obesity, diabetes, chronic kidney failure or alcohol consumption. ${ }^{3}$ Chen and Shen described an association of juvenile gout with overweight and hereditary background in a case series of 543 patients. ${ }^{4}$ Considering the aggressiveness of the disease, early diagnosis and treatment of this subgroup of patients are essential, in order to prevent potential clinical consequences, including cardiovascular and renal disease.
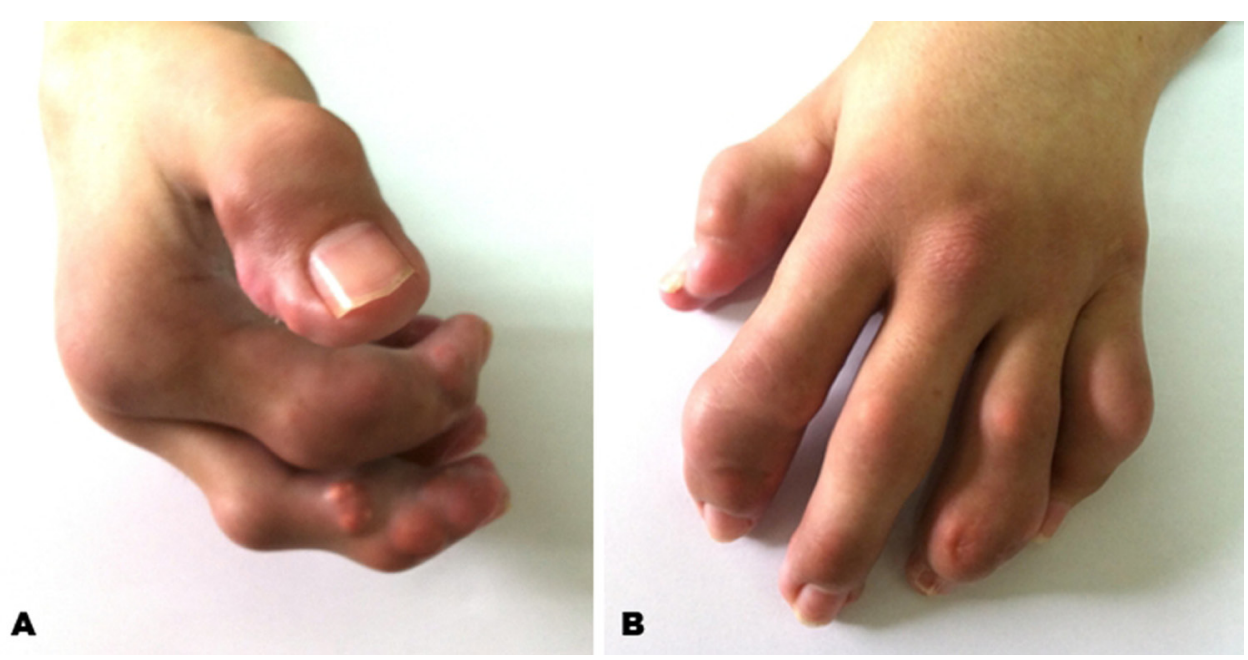

Figure 1 (A, B) Asymmetric articular deformity of both hands. 


\section{BMJ Case Reports}

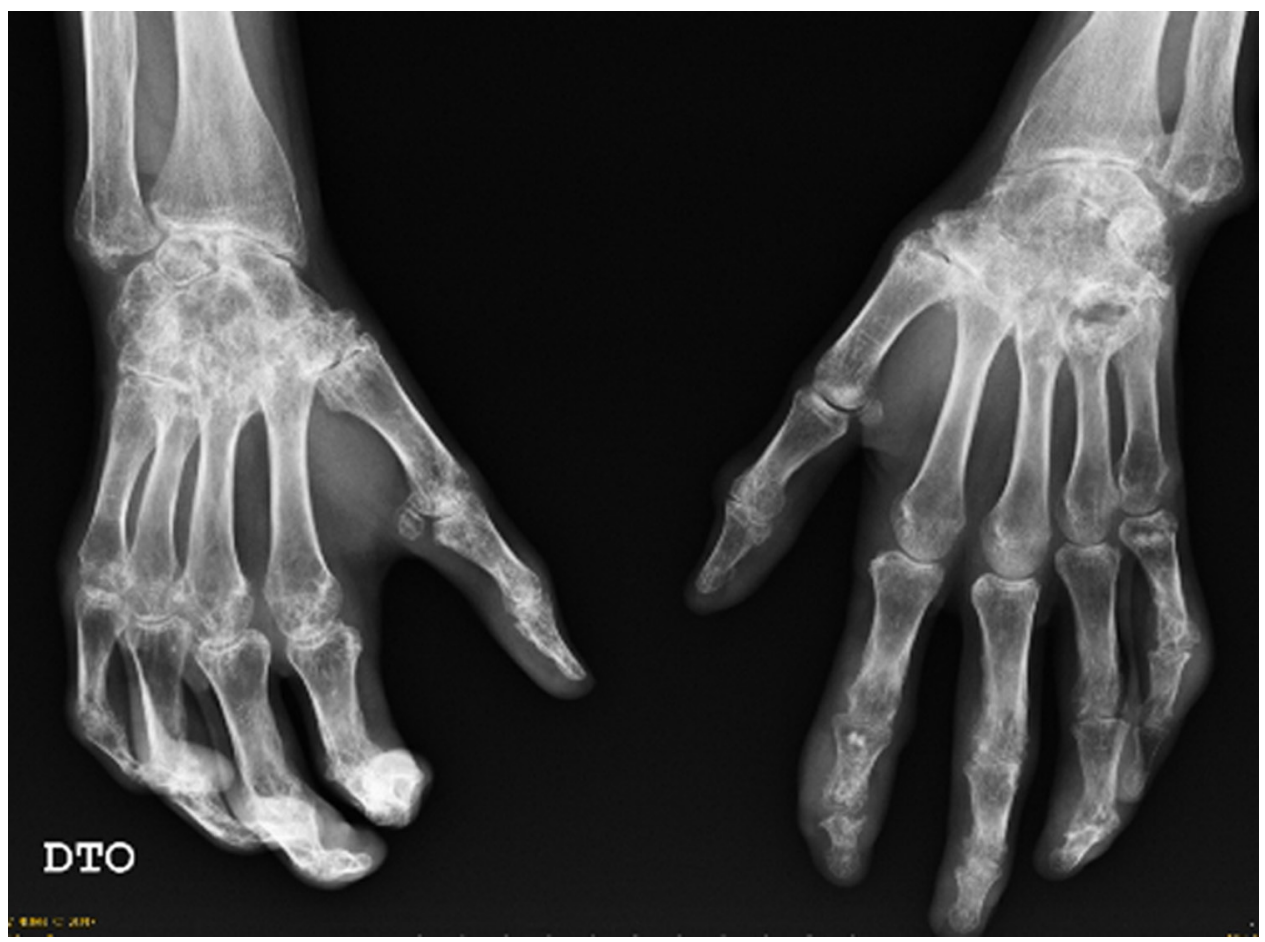

Figure 2 Hands x-ray revealing asymmetrical joint destruction in carpal and distal interphalangeal joints.

\section{Learning points}

- Gout is the commonest inflammatory arthritis.

- Juvenile arthritis is rare and may be associated with other underlying diseases or reversible disorders.

- The early diagnosis and treatment of gout may alter the clinical course of the disease and prevent progression to kidney and cardiovascular damage.
Competing interests None.

Patient consent Obtained.

\section{REFERENCES}

1. Roddy E, Doherty M. Epidemiology of gout. Arthritis Res Ther 2010;12:223.

2. Pouye A, Fall $S$, Diallo $S$, et al. [Polyarticular gout in young adults: a curable rheumatic disease]. Med Trop (Mars) 2006;66:273-6.

3. Yamanaka H. Gout and hyperuricemia in young people. Curr Opin Rheumatol 2011;23:156-60.

4. Chen SY, Shen ML. Juvenile gout in Taiwan associated with family history and overweight. J Rheumatol 2007;34:2308-11.

This pdf has been created automatically from the final edited text and images.

Copyright 2012 BMJ Publishing Group. All rights reserved. For permission to reuse any of this content visit http://group.bmj.com/group/rights-licensing/permissions.

BMJ Case Report Fellows may re-use this article for personal use and teaching without any further permission.

Please cite this article as follows (you will need to access the article online to obtain the date of publication).

Henriques CC, Monteiro A, Lopéz B, Sequeira L, Panarra A, Riso N. Juvenile gout: rare and aggressive. BMJ Case Reports 2012; 10.1136/bcr.12.2011.5345, Published XXX

Become a Fellow of BMJ Case Reports today and you can:

- Submit as many cases as you like

- Enjoy fast sympathetic peer review and rapid publication of accepted articles

- Access all the published articles

- Re-use any of the published material for personal use and teaching without further permission

For information on Institutional Fellowships contact consortiasales@bmjgroup.com

Visit casereports.bmj.com for more articles like this and to become a Fellow

Keep up to date with all published cases by signing up for an alert (all we need is your email address) http://casereports.bmj.com/cgi/alerts/etoc 